DOI:10.1515/curie-2015-0038

\begin{tabular}{lcr}
\hline \multicolumn{1}{c}{ A N N A L E S } \\
UNIVERSITATIS & MARIAE CURIE-SKŁODOWSKA \\
LUBLIN - POLONIA & \\
VOL. XXII, 2 & SECTIOK & 2015 \\
\hline
\end{tabular}

Wydział Politologii Uniwersytetu Marii-Curie Skłodowskiej w Lublinie

\author{
MARCIN POMARAŃSKI
}

\title{
Amerykańskie ruchy secesjonistyczne w XXI wieku na przyktadzie Kalifornii
}

American Secessionist Movements in the Twenty-First century. Case study: California

\begin{abstract}
ABSTRAKT
Celem artykułu jest odpowiedź na pytanie o stan i rozmiar amerykańskich ruchów secesjonistycznych w XXI w. W szczególności przedmiotem rozważań stanie się analiza przedsięwzięć secesjonistycznych dotyczących Kalifornii: próba uchwycenia istoty proponowanych przez takie projekty zmian politycznych, wskazanie przyczyn wysnuwania tak radykalnych żądań oraz przedstawienie potencjalnych form oddziaływania społecznego tych projektów na Złoty Stan i jego mieszkańców. Odwołanie się do przykładu Kalifornii wydaje się tu szczególnie uzasadnione. Jako trzeci pod względem wielkości, a pierwszy jeśli chodzi o liczbę mieszkańców stan USA, może się ona poszczycić niezwykle bogatą tradycją niepodległościową, skutkującą na przestrzeni 165 lat obecności w Unii setkami przeróżnych przedsięwzięć dążących do podziału bądź niezależności dla tego obszaru.
\end{abstract}

Stowa kluczowe: secesja, ruch secesjonistyczny, Kalifornia

\section{WSTĘP}

W 2013 r. w USA w trakcie wystąpienia w ramach „Startup School 2013” wykładowca Uniwersytetu Stanforda i założyciel firmy technologicznej Counsyl - Balaji Srinivasan - podjął problem secesji politycznej w niespotykanym dotychczas wymiarze. Analizując innowacyjny potencjał Krzemowej Doliny, zasugerował, że region powinien odłączyć się od Stanów Zjednoczonych. Porzucenie dotychczasowych struktur państwowych miałoby się odbyć jednak na rzecz państwa wirtualnego istniejącego jedynie w Internecie. W ten sposób naukowcy i przedsiębiorcy z Kalifornii nie byliby ograniczani hamującymi technologiczny postęp i gospodarczą prosperitę decyzjami 
politycznymi, a ich niezależność od partyjnych interesów i konieczności schlebiania masowemu wyborcy przełożyłaby się na efektywniejszą pracę. Uzasadniając swój pomysł, Srinivasan zauważył, że wirtualna secesja najbardziej innowacyjnego obszaru USA już następuje: „Netflix i iTunes to platformy do pobierania i przekazu rozrywki. Twitter i blogi przejmują rolę tradycyjnych mediów. Khan Academy i Coursera konkurują z uniwersytetami, a drukarki 3D sprawiają, że niemożliwy jest zakaz posiadania i kontroli jakiegokolwiek obiektu fizycznego, w tym broni czy drona. Z kolei dzięki walucie Bitcoin każdy może sobie stworzyć własny raj podatkowy. Secesja zorientowanej technologicznie i przyszłościowo klasy średniej z tradycyjnego państwa to tylko kwestia czasu" [Sarnacka-Mahoney 2013; Srinivasan 2013].

Wystąpieniem tym Srinivasan nadał nowy wymiar problemowi towarzyszącemu Stanom Zjednoczonym od początku ich istnienia. Pod całą technologiczno-cyfrową otoczką ukrył bowiem odżywające co jakiś czas w różnych częściach kraju postulaty secesjonizmu politycznego, stanowiące dla Amerykanów zaskakująco powszechny sposób wyrażania swojego niezadowolenia z istniejącej sytuacji politycznej czy gospodarczej. W środowiskach naukowych panuje dość powszechna zgoda, że z secesją mamy do czynienia w sytuacjach, gdy „znaczna część populacji zamieszkująca określone terytorium danego państwa, wyraża werbalnie lub w działaniu wolę ustanowienia własnego niepodległego tworu państwowego lub przyłączenia się do innego suwerennego państwa" [Pavkovic, Radan 2007: 6]. Jednakże, przypadek federacyjnego charakteru państwa amerykańskiego, jak również fakt znacznej autonomii i różnorodności wchodzących w jego skład stanów, nakazuje pamiętać o rozszerzeniu powyższej definicji także o „wymiar regionalny” uwzględniający przypadki, w których grupy obywateli żądają zmiany istniejących granic pomiędzy stanami, podważając istniejący w USA podział administracyjny.

Celem niniejszej pracy będzie odpowiedź na pytanie o stan i rozmiar amerykańskich ruchów secesjonistycznych w XXI w. W związku z tym podjęta zostanie próba uchwycenia specyfiki tego zjawiska politycznego. Odwołanie się do przykładu Kalifornii wydaje się tu szczególnie uzasadnione. Jako trzeci pod względem wielkości, a pierwszy jeśli chodzi o liczbę mieszkańców i średni roczny dochód na osobę ${ }^{1}$ stan USA może się ona poszczycić niezwykle bogatą tradycją niepodległościową, skutkującą na przestrzeni 165 lat obecności w Unii setkami przeróżnych przedsięwzięć dążących do podziału bądź niezależności dla tego obszaru [Gall 2007: 73-74, 91]. Przedmiotem rozważań w niniejszym artykule jest analiza przedsięwzięć secesjonistycznych dotyczących Kalifornii, które zostały zainicjowane w XXI w., a w szczególności: próba uchwycenia istoty proponowanych przez takie projekty zmian politycznych, wskazanie przyczyn wysnuwania tak radykalnych żądań oraz przedstawienie potencjalnych form oddziaływania społecznego tych projektów na Złoty Stan i jego

1 Według danych z 2007 r. od tego czasu ranking stanów USA pod względem średniego rocznego dochodu na osobę uległ zmianom. Kalifornia straciła pozycję lidera, choć wciąż jest w pierwszej dziesiątce. Zob. strona internetowa United States Census Bureau, http://www.census.gov/ (dostęp: 29.12.2015). 
mieszkańców. Działania te poprzedzono także próbą wyjaśnienia przyczyn znacznej popularności postulatów secesjonistycznych właśnie wśród mieszkańców Kalifornii.

\section{SPECYFIKA WSPÓŁCZESNEGO SECESJONIZMU W USA}

Niezwykle trudno dokonać charakterystyki współczesnych amerykańskich ruchów secesjonistycznych. Wynika to przede wszystkim z liczby i różnorodności takich projektów. W ciągu ostatnich trzech dekad na terenie USA pojawiło się ponad 60 tego typu przedsięwzięć. Wyróżniają się one odmienną motywacją do działania, stawiają sobie rozmaite cele polityczne, a także działają na nieporównywalnie różne skale - zaczynając od przedsięwzięć ograniczonych do terenu jednego czy kilku hrabstw, a kończąc na propozycjach domagających się niepodległości dla określonej liczby sąsiadujących ze sobą stanów. Każdy z tych projektów wraz z własną wizją nowego porządku społecznego i politycznego kształtuje obraz współczesnego amerykańskiego secesjonizmu. Sytuacji nie ułatwia również podział administracyjny USA, w którym dysponujące określonym poziomem samodzielności politycznej stany mogą antagonizować istniejące spory terytorialne nawet niezależnie od stanowiska rządu federalnego. Biorąc to wszystko pod uwagę, można jednak wyróżnić przynajmniej trzy fundamentalne właściwości współczesnych amerykańskich projektów secesjonistycznych, charakterystyczne jeśli nie dla wszystkich to przynajmniej dla znacznej części tego typu projektów.

Po pierwsze, są to w większości wypadków przedsięwzięcia lokalne, ograniczone terytorialnie do obszaru co najwyżej kilku hrabstw. Znaczna ich część nawet nie ma ambicji niepodległościowych, walcząc raczej o jakąś formę autonomii lub zmianę podziału administracyjnego spornego obszaru. Jedynie co szósty przykład takiego ruchu politycznego mógłby zostać określony mianem „dużego”, postulując niepodległość jednego lub kilku stanów USA, a i one z perspektywy całego ogromnego obszaru Stanów Zjednoczonych nabierają jedynie regionalnego kolorytu ${ }^{2}$. Owa lokalność współczesnego secesjonizmu amerykańskiego nie jest determinowana bowiem tylko rozmiarami spornego terytorium, lecz także przywiązaniem do rodzimej kultury, nieco odmiennej dla poszczególnych regionów, a nawet dla poszczególnych stanów. To ona sprawia, że obywatele USA postrzegają swoją tożsamość nie tylko w kategoriach narodowych, lecz także w regionalnych i lokalnych, np. mieszkaniec Środkowego-Zachodu (Midwest), reprezentant Pasa Biblijnego ${ }^{3}$, Teksańczyk

2 Z wyjątkiem projektów: „Południowe Stany Zjednoczone” czy „Skonfederowane Stany Ameryki”, które domagają się niepodległości - odpowiednio 14 i 11 stanów USA. Por. strony organizacji secesjonistycznych League of the South i Southern National Congress, http://leagueofthesouth.com/; http:// www.southernnationalcongress.org/ (dostęp: 29.12.2015).

3 Pas Biblijny (ang. Bible Belt) to określenie obszaru amerykańskiego Południa (zazwyczaj: Floryda, Alabama, Tennessee, Kentucky, Georgia, Północna i Południowa Karolina, Wirginia, Teksas, Arkansas i Luizjana) bardziej chrześcijańskiego i konserwatywnego niż reszta USA [Pomarański 2013: 123]. 
czy Amerykanin ze Wschodniego Wybrzeża. W przypadku współczesnych ruchów secesjonistycznych owe lokalne wyróżniki kultury stają się istotnymi elementami charakterystyki nowych projektów politycznych. Ułatwia to adaptację postulatów secesjonistycznych wśród mieszkańców spornego terytorium i zarysowuje wyraźną granicę pomiędzy ruchem a rządem federalnym utożsamianym $\mathrm{z}$ istniejącym stanem rzeczy. Znajduje to również swoje odzwierciedlenie w wymiarze jakościowym projektów secesjonistycznych, racjonalizując oczekiwania polityczne, które w przeważającej części, jak już zostało wspomniane powyżej, dotyczą nie tyle zerwania wszelkich administracyjnych więzi z USA, co wyrażają niezadowolenie z przebiegu granic pomiędzy stanami czy hrabstwami, domagając się ich zdecydowanej rewizji.

Kolejną właściwością amerykańskich ruchów secesjonistycznych, która po części łączy się z pierwszą, jest przywiązanie do tradycji niepodległościowej USA. Wyraża się ona: 1) pamięcią o bohaterach i ideałach rewolucji amerykańskiej, która doprowadziła do uniezależnienia się nowego państwa od Wielkiej Brytanii, a także 2) sentymentem wobec dziejów własnego stanu, w szczególności sprzed włączenia go do Unii. Dla współczesnych secesjonistów wyrazem tego pierwszego jest niemal nabożny stosunek wobec „Deklaracji Niepodległości” z 1776 r., która już w pierwszych swoich wersach potwierdza prawo obywateli USA do zmiany rządu: „Uważamy następujące prawdy za oczywiste: że wszyscy ludzie stworzeni są równymi, że Stwórca obdarzył ich pewnymi nienaruszalnymi prawami, że w skład tych praw wchodzi życie, wolność i swoboda ubiegania się o szczęście, że celem zabezpieczenia tych praw wyłonione zostały wśród ludzi rządy, których sprawiedliwa władza wywodzi się ze zgody rządzonych, że jeżeli kiedykolwiek jakakolwiek forma rządu uniemożliwiałaby osiągnięcie tych celów, to naród ma prawo taki rząd zmienić lub obalić i powołać nowy, którego podwalinami będą takie zasady i taka organizacja władzy, jakie wydadzą się narodowi najbardziej sprzyjające dla szczęścia i bezpieczeństwa" [Bartnicki, Michałek, Rusinowa 1992: 67-68].

W przypadku ruchów secesjonistycznych ze Złotego Stanu ów sentyment wobec dziejów regionu znajduje odzwierciedlenie we wciąż podtrzymywanej tradycji Republiki Kalifornii. Było to niepodległe państwo istniejące niecały miesiąc w $1846 \mathrm{r}$. (14 czerwca - 9 lipca) utworzone przez osadników amerykańskich na terytorium meksykańskiej Kalifornii Północnej (hiszp. Alta California). W momencie gdy do secesjonistów dotarła informacja o wybuchu wojny pomiędzy Stanami Zjednoczonymi a Meksykiem, republika została rozwiązana, a osadnicy skoncentrowali się na walce po stronie amerykańskiej. Skutkiem tego obszar kilkutygodniowej republiki stał się przedmiotem sporów politycznych i został przyłączony do terytorium USA cztery lata później jako 31 stan [Janiskee, Masugi 2004: 1-373]. Tradycja republiki z 1846 r. jest wciąż żywa wśród obywateli Kalifornii, czego namacalnym dowodem jest jej flaga stanowa $z$ niedźwiedziem i gwiazdą będąca jedynie nieznaczną przeróbką sztandaru z połowy XIX w. Dla kalifornijskich secesjonistów odwołanie się do tradycji republiki z 1846 r., jak również przepisy „Deklaracji Niepodległości” stanowią nie tylko symboliczny wyraz idei republikańskich znajdujących się 
u podstaw państwowości amerykańskiej, ale aktualne uprawnienie obywateli, mające realne skutki legislacyjne. Zgodnie z takim podejściem zapisy te upoważniają społeczeństwo lub jego część do zerwania w każdej chwili więzów państwowych i samodzielnego decydowania o swojej politycznej afiliacji.

Trzecia właściwość wspólna dla amerykańskich ruchów secesjonistycznych jest charakterystyczna dla wszystkich tego typu przedsięwzięć na świecie i wynika z konieczności skazania ruchów politycznych dążących do oderwania się od określonego państwa lub stanu na konflikt $\mathrm{z}$ istniejącą na tym terenie administracją rządową i samorządową. Wpisując się w standardy demokratyczne, ,amerykańskie” przedsięwzięcia secesjonistyczne niemal zupełnie odrzucają możliwość stosowania walki zbrojnej do realizacji swoich celów. Ich działania polegają w głównej mierze na mobilizacji opinii publicznej zamieszkującej sporny teren do poparcia planów niepodległościowych, co ma znaleźć swoje odzwierciedlenie najpierw w wynikach lokalnych wyborów, a docelowo w masowym poparciu idei niezależności w referendum, plebiscycie czy innej formie demokracji bezpośredniej.

W praktyce aktywność taka oznacza jednak dla przedstawicieli ruchów secesjonistycznych walkę polityczną przeciwko opresyjnie nastawionemu aparatowi państwowemu albo prezentującym odmienny punkt widzenia reprezentantom tego aparatu skupionym w partiach politycznych i innych grupach interesu. Zdecydowanie najpopularniejszym przeciwnikiem dla amerykańskich secesjonistów stał się rząd federalny, postrzegany jako narzucona siłą władza, która nie dysponuje prawną legitymizacją na terenie poszczególnych stanów. Jego działalność mająca na celu bagatelizowanie bądź tłumienie pojawiających się postulatów niepodległościowych pogłębia dodatkowo konfrontacyjny charakter problemu. Nigdy bowiem istniejące państwo nie pozostawi bez odpowiedzi postulatów zagrażających jego integralności [Pavkovic, Radan 2007: 5]. Czy to za pomocą własnych agend, czy też przez organizacje społeczne i polityczne wyraża ono sprzeciw wobec naruszania jedności terytorium, organizując przedsięwzięcia mające zdyskredytować w oczach społeczeństwa postulaty poszczególnych ruchów proniepodległościowych.

\section{UWARUNKOWANIA KALIFORNIJSKICH NASTROJÓW SECESJONISTYCZNYCH}

Wspomniana powyżej Republika Kalifornii to najważniejsze historyczne odniesienie dla współczesnych secesjonistów z terytorium Złotego Stanu. Choć jej 25-dniowe istnienie stanowi mało znaczący epizod w dziejach kontynentu amerykańskiego, to dla samych mieszkańców tej części USA jest ona dowodem na posiadanie wciąż nieograniczonej suwerenności politycznej. Sentyment ten znalazł swoje odzwierciedlenie w oficjalnej symbolice stanu, jak również w przekonaniu znacznej części jego mieszkańców o umowności i dobrowolności wszelkich istniejących podziałów administracyjnych. Stało się to wyrazem zaskakującej determinacji obywateli amerykańskich zamieszkujących Kalifornię do formułowania przeróżnych 
postulatów secesjonistycznych w tym żądań: podziału stanu na kilka, przyznania mu pełnej niepodległości czy oderwania od niego określonych terenów. Od momentu przyłączenia stanu do Unii w 1850 r. do końca XX w. publicznie ogłoszono na tym obszarze ponad 220 tego typu projektów, co stanowi więcej niż jeden nowy postulat secesjonistyczny rocznie [Wood 2011]. Choć stopień powagi i realności owych projektów politycznych był niezwykle zróżnicowany, sama ich liczba uzmysławia, że historycznie kultywowana idea samostanowienia jest wciąż dla Kalifornijczyków aktualnym uprawnieniem.

Analiza retoryki towarzyszącej najważniejszym projektom secesjonistycznym w dziejach Kalifornii, a w szczególności motywom, które pchały wciąż nowe grupy i organizacje do walki o administracyjne zmiany na mapie Złotego Stanu, pozwalają wskazać główne przyczyny powszechności secesjonizmu na tym obszarze. W pierwszej kolejności wpływa na to bez wątpienia czynnik geograficzny. Kalifornia jest jedynym amerykańskim stanem, na terenie którego obok rozległego wybrzeża morskiego występują łańcuchy górskie i pustynie. Znaczna liczba wysokich gór ${ }^{4}$, jak również ogromne różnice poziomu terenu to tylko niektóre z cech topograficznych tej części kontynentu ${ }^{5}$. Wysokie łańcuchy górskie na czele ze Sierra Nevada we wschodniej części stanu i Górami Nadbrzeżnymi w zachodniej już od początków osadnictwa utrudniały komunikację pomiędzy poszczególnymi częściami Kalifornii, skłaniając do formułowania pomysłów secesjonistycznych. Przykładowo trudności w pokonywaniu pasma Tehachapi Mountains wchodzącego w skład tych ostatnich były przyczyną debat secesjonistycznych już pod koniec XIX w. W 1978 r. na tę samą przyczynę powołał się przedstawiciel Zgromadzenia Stanowego Kalifornii Barry Keene, proponując podział stanu wzdłuż wspomnianego pasma górskiego na „Alta California” (część północna) i „Central California” (część południowa) [Di Leo, Smith 1983: 78-79].

Kolejnym czynnikiem sprzyjającym tworzeniu nowych projektów secesjonistycznych wśród mieszkańców Złotego Stanu jest zróżnicowanie kulturowe regionu. Kalifornię charakteryzuje największa liczba mieszkańców ze wszystkich 50 stanów USA. Według spisu z 2005 r. wynosiła ona ponad 36 milionów ludzi i osiągała prawie $7 \%$ wzrostu w skali roku ${ }^{6}$. Za ów wzrost odpowiadała przede wszystkim imigracja ekonomiczna z całego świata, która uczyniła z miast kalifornijskich, na czele z Los Angeles i San Francisco, prawdziwe tygle wielokulturowe. Wśród trendów imigracyjnych wyróżniał się (i wciąż wyróżnia) napływ ludności z Meksyku czy państw Ameryki Środkowej. W 2004 r. 34,7\% całej populacji stanu miało pochodzenie latynoamerykańskie, wykazując w związku z tym większe przywiązanie do kultury hiszpańskojęzycznej i do katolicyzmu niż do etosu tradycyjnych WASPów (Amery-

4 Na terenie stanu istnieje 41 gór o wysokości powyżej 3000 m n.p.m.

5 Przykładem tego może być chociażby fakt, że najwyższy szczyt Kalifornii (Mt. Whitney - $4419 \mathrm{~m}$ ) znajduje się niecałe 130 km od najniższego miejsca w kraju (Dolina Śmierci - 86 m p.p.m.) [Gall 2007: 73].

6 Według szacunków wówczas poczynionych w 2015 r. liczba mieszkańców stanu miała przekroczyć 40 milionów, ale dane statystyczne United States Census Bureau na koniec 2015 r. mówiły ,,jedynie” o osiągniętej liczbie 39 milionów mieszkańców [Annual Estimates... 2015]. 
kanów anglosaskiego pochodzenia wyznających protestantyzm) ${ }^{7}$. Od czasów II wojny światowej ludność ta osiedlała się zwyczajowo w południowej części Kalifornii, tworząc tam wpływowe kręgi społeczne i polityczne. Ich obecność w konsekwencji determinowała następujące zmiany struktury demograficznej i kulturowej tych terenów. Już na przełomie XX i XXI w. ludność pochodzenia latynoamerykańskiego stała się najliczniejszą grupą etniczną w południowej Kalifornii, osiągając w Los Angeles w 2005 r. poziom 47,5\% całej populacji miasta [Gall 2007: 78-79]. Stanowi to wyraźny kontrast w stosunku do północnej części stanu, stając się przyczyną coraz to nowych pomysłów podziału obszaru według kryteriów kulturowo-etnicznych.

W przypadku kalifornijskich ruchów secesjonistycznych na powyższe rozbieżności nakładają się zazwyczaj kolejne różnice mające charakter polityczny, ekonomiczny, ekologiczny czy infrastrukturalny. W większości wypadków stanowią one subiektywne pogłębienie dysproporcji wynikających z lokalizacji czy też struktury etniczno-kulturowej Kalifornii. Ich wspólną właściwością jest powszechny wyraz niezadowolenia społecznego z: określonych decyzji władz federalnych czy lokalnych, nierówności w poziomie zarobków występujących w różnych częściach stanu, a nawet kontrowersyjnych regulacji środowiskowych. W takich wypadkach określone grupy interesu próbują blokować niepopularne decyzje, wyrażając swój sprzeciw i nawołując do podziału stanu wzdłuż bardziej „naturalnych” granic. Wymownym tego przykładem mogą się stać dwie propozycje secesjonistyczne ogłoszone i promowane przez lokalnych polityków: Randolpha Colliera w 1970 r. oraz Stana Stathama w 1992 r. Choć projekty te zakładały całkowicie odmienne sposoby podziału Kalifornii ${ }^{8}$, to obydwu przyświecała podobna motywacja - pragnienie rozwiązania piętrzących się w Złotym Stanie sporów politycznych związanych z asymetrycznym rozwojem miejskich i rolniczych części regionu czy kompletnie różnymi wizjami na temat społecznej i ekonomicznej roli Kalifornii w gospodarce USA [Di Leo, Smith 1983: 71; Kamber 1995: 38].

Tab. 1. Najważniejsze projekty secesjonistyczne w Kalifornii w latach 1850-2000

\begin{tabular}{|c|l|l|}
\hline Rok & \multicolumn{1}{|c|}{ Proponowane zmiany } & Oficjalne przyczyny secesji \\
\hline 1855 & $\begin{array}{l}\text { Podział terytorium na trzy stany: Kolorado (południowa część), } \\
\text { Shasta (północna część), Kalifornia (centralna część) }\end{array}$ & Zbyt duży rozmiar terytorium \\
\hline 1859 & $\begin{array}{l}\text { Podział terytorium stanu wzdłuż równoleżnika 36 stopnia szero- } \\
\text { kości geograficznej północnej na Kalifornię (część północna) oraz } \\
\text { Kolorado (część południowa) }\end{array}$ & $\begin{array}{l}\text { Geograficzne i kulturowe róż- } \\
\text { nice pomiędzy północną i połu- } \\
\text { dniową częścią stanu }\end{array}$ \\
\hline 1881 & $\begin{array}{l}\text { Pomysł połączenia obszarów Los Angeles, San Diego oraz San Ber- } \\
\text { nardino z terytorium Arizony pod wspólną nazwą,„Calizonia” }\end{array}$ & $\begin{array}{l}\text { Niezadowolenie z wyników wy- } \\
\text { borów do legislatury stanowej }\end{array}$ \\
\hline 1888 & $\begin{array}{l}\text { Propozycja utworzenia stanu „Południowej Kalifornii” (Southern } \\
\text { California) złożona przez lokalnego polityka Williama Vandevera }\end{array}$ & $\begin{array}{l}\text { Kulturowe rozbieżności pomię- } \\
\text { dzy północną i południową czę- } \\
\text { ścią stanu }\end{array}$ \\
\hline
\end{tabular}

\footnotetext{
7 Od ang. White Anglo-Saxon Protestant.

8 Randolph Collier chciał utworzenia Kalifornii Wschodniej i Zachodniej, natomiast Stan Statham - Kalifornii Północnej, Środkowej i Południowej.
} 


\begin{tabular}{|c|c|c|}
\hline 1921 & $\begin{array}{l}\text { Propozycja wyodrębnienia } 8 \text { południowych hrabstw Kalifornii } \\
\text { w osobny stan przygotowana przez polityka W.F. Beala z Hrabstwa } \\
\text { Imperial }\end{array}$ & $\begin{array}{l}\text { Zbyt duże różnice kulturowe } \\
\text { w stosunku do reszty stanu }\end{array}$ \\
\hline 1941 & $\begin{array}{l}\text { Pomysł połączenia północnej Kalifornii (hrabstwa: Del Norte, Si- } \\
\text { skiyou, Modoc) z południowym Oregonem (hrabstwa: Curry, Jo- } \\
\text { sephine, Jackson, Klamath) w nowy stan „Jefferson” (State of Jef- } \\
\text { ferson) }\end{array}$ & $\begin{array}{l}\text { Protest przeciwko infrastruk- } \\
\text { turalnym i ekonomicznym za- } \\
\text { niedbaniom tych terenów przez } \\
\text { władze federalne i stanowe } \\
\end{array}$ \\
\hline 1956 & $\begin{array}{l}\text { Pomysł utworzenia w północnej Kalifornii stanu Shasta (State of } \\
\text { Shasta) }\end{array}$ & $\begin{array}{l}\text { Protest przeciwko nadmiernej } \\
\text { eksploatacji zasobów wodnych } \\
\text { tych terenów przez resztę stanu }\end{array}$ \\
\hline 1965 & $\begin{array}{l}\text { Propozycja senatora stanowego Richarda Dolwiga podzielenia sta- } \\
\text { nu na dwie części z granicą na łańcuchu górskim Tehachapi }\end{array}$ & $\begin{array}{l}\text { Wśród przyczyn wymieniano } \\
\text { zarówno uwarunkowania geo- } \\
\text { graficzne, motywy ekologiczne, } \\
\text { jak i wyraźne rozbieżności po- } \\
\text { lityczne }\end{array}$ \\
\hline 1970 & $\begin{array}{l}\text { Propozycja senatora stanowego Randolpha Colliera utworzenia } \\
\text { Kalifornii Wschodniej (Eastern California) i Kalifornii Zachodniej } \\
\text { (Western California) }\end{array}$ & $\begin{array}{l}\text { Sposób na rozwiązanie piętrzą- } \\
\text { cych się w Kalifornii sporów } \\
\text { regionalnych i lokalnych }\end{array}$ \\
\hline 1975 & $\begin{array}{l}\text { W opublikowanej przez Ernesta Callenbacha książce Ecotopia po- } \\
\text { jawia się wizja niepodległego państwa utworzonego z terenów pół- } \\
\text { nocnej Kalifornii oraz stanów Oregon i Waszyngton. Wizja literacka } \\
\text { staje się impulsem utworzenia ruchu secesjonistycznego, który chce } \\
\text { te tereny przekształcić w niezależny twór Casacdię }\end{array}$ & $\begin{array}{l}\text { Główną przyczyną są względy } \\
\text { ekologiczne - pragnienie ochro- } \\
\text { ny bioróżnorodności tych tere- } \\
\text { nów przed zniszczeniem }\end{array}$ \\
\hline 1978 & $\begin{array}{l}\text { Propozycja przedstawiciela Zgromadzenia Stanowego Kalifornii } \\
\text { Barry’ego Keene’a podziału stanu wzdłuż pasma górskiego Te- } \\
\text { hachapi Mountains na północną - „Alta California” i południową } \\
\text { „Central California” }\end{array}$ & $\begin{array}{l}\text { Trudności geograficzne w ko- } \\
\text { munikacji pomiędzy obydwiema } \\
\text { częściami stanu oraz wynikające } \\
\text { z nich przesłanki gospodarcze } \\
\end{array}$ \\
\hline 1992 & $\begin{array}{l}\text { Propozycja przedstawiciela Zgromadzenia Stanowego Kalifornii } \\
\text { Stana Stathama przeprowadzenia referendum we wszystkich hrab- } \\
\text { stwach w sprawie przynależności do jednego z trzech nowych sta- } \\
\text { nów: Północnej, Środkowej lub Południowej Kalifornii }\end{array}$ & $\begin{array}{l}\text { Sposób na rozwiązanie piętrzą- } \\
\text { cych się w Kalifornii sporów } \\
\text { regionalnych i lokalnych }\end{array}$ \\
\hline
\end{tabular}

Źródło: Opracowanie własne na podstawie: Ellison 1913: 101-139; Di Leo, Smith 1983: 6-7, 39-158; Evans 2002.

\section{SECESJONIZM KALIFORNIJSKI W XXI WIEKU}

Od początku XXI w. na terenie Kalifornii ogłoszono pięć propozycji podziału stanu. W trzech przypadkach pomysły te polegały na mniej lub bardziej twórczym przeformułowaniu projektów pojawiających się już wcześniej. W ten sposób lokalny polityk republikański Bill Maze w 2009 r. zaadaptował idee sformalizowane w latach 70. XX w. i ponownie ogłosił pomysł podzielenia stanu na część zachodnią oraz wschodnią, zapowiadając w konsekwencji wyodrębnienie nowej Kalifornii Nadbrzeżnej (Coastal California). Propozycja, która miała być odpowiedzią na dręczącą Złoty Stan recesję, została jednogłośnie wyśmiana przez opinię publiczną, a lokalni publicyści przez kilka tygodni rywalizowali w wymyślaniu coraz bardziej bezsensownych nazw dla nowych tworów politycznych. Jednym z gorliwych krytyków tego przedsięwzięcia był dziennikarz tygodnika „Tha Nation” Peter Schrag. Wskazując gospodarczy bezsens takiego pomysłu, zwrócił uwagę na brak rozwiniętego przemysłu we wschodniej części Kalifornii. Miało to grozić ekonomiczną katastrofą dla 
terenu, który byłby zmuszony „sprzedawać swoją wodę pitną i miejsca w więzieniach bardziej rozwiniętym stanom"9.

W podobny sposób zakończyły się dwa kolejne przedsięwzięcia secesjonistyczne: podjęty w 2011 r. pomysł lokalnego polityka republikańskiego z Hrabstwa Riverside Jeffa Stone' a wyodrębnienia po raz kolejny Kalifornii Południowej oraz powrót w 2013 r. po ponad 70 latach do idei niezależnego stanu Jefferson zainicjowany przez grupę entuzjastów, której twarzą stał się Mark Baird, działacz lokalny z Hrabstwa Modoc. Obydwie inicjatywy zostały publicznie wyśmiane. Propozycja Stone'a została skompromitowana nawet przez samego gubernatora Kalifornii Jerry’ego Browna, który określił ją mianem ,absurdalnej”, a ustami swojego rzecznika prasowego nazwał ją „niezwykle śmieszną stratą czasu” dla wszystkich mieszkańców Złotego Stanu [Allen 2011]. Nieznacznie bardziej stonowane stanowisko gubernator zajął wobec inicjatywy Bairda, unikając jednoznacznych opinii na ten temat i zapewniając, że „spotka się z mieszkańcami popierającymi secesję i przekona ich do pozostania w ramach jednej Kalifornii” [Bluff 2014].

Nieco bardziej oryginalną propozycję secesjonistyczną sformułowano już w 2003 r. w ferworze komentarzy i podsumowań po odwołaniu ze stanowiska demokratycznego gubernatora Josepha Grahama Davisa i zastąpieniu go reprezentującym Partię Republikańską Arnoldem Schwarzeneggerem. Oceniając wyniki głosowania mieszkańców poszczególnych rejonów Kalifornii, publicysta Tim Holt zaproponował rozbicie stanu na mniejsze jednostki wzdłuż wyraźnie zarysowanych linii podziału politycznego. W swoim artykule przyznał on prawo do istnienia czterem niezależnym tworom administracyjnym: znajdującym się w północnej części stanu zdecydowanie bardziej konserwatywnym Redwood Coast i Shasta/Jefferson, a także liberalnym terenom Bay Area, obejmującym obszar wokół San Francisco, oraz sięgającej południowych krańców Złotego Stanu Central Valley. Przedsięwzięcie Holta, choć znalazło grupę oddanych zwolenników, nigdy nie przerodziło się w zorganizowany ruch społeczny. Nigdy nawet nie wyszło poza ramy komentarza prasowego mówiącego więcej o wewnętrznych problemach politycznych Kalifornii niż o nastrojach secesjonistycznych jej mieszkańców [Holt 2003].

Najbardziej ambitnym projektem podziału Kalifornii w XXI w., zarówno pod względem proponowanych zmian administracyjnych, jak i z punktu widzenia społecznego zaangażowania w ich realizację, stanowi najnowsze przedsięwzięcie inwestora finansowego z Doliny Krzemowej Tima Drapera. W grudniu 2013 r. złożył on do biura Prokuratora Generalnego Kalifornii propozycję przeprowadzenia referendum w sprawie rozbicia stanu na sześć części: Jefferson (Jefferson), Kalifornia Zachodnia (West California), Krzemowa Dolina (Silicon Valley), Kalifornia Środkowa (Central California), Kalifornia Północna (North California), Kalifornia Południowa (South

9 Wyrażając bezsensowność propozycji Maze'a, Peter Schrag zaproponował również nazwanie Kalifornii Wschodniej mianem „Appalachifornii” od systemu górskiego odległego o ponad $2000 \mathrm{~km} \mathrm{i} \mathrm{znaj-}$ dującego się na wschodnim wybrzeżu USA [Mathews, Paul 2010: 154-155]. 
California). W uzasadnieniu do wniosku zauważył, że Złoty Stan ma sześciokrotnie więcej mieszkańców niż wynosi średnia dla całych Stanów Zjednoczonych. $\mathrm{W}$ połączeniu z jej rozmiarem prowadzi to do sytuacji uniemożliwiającej sprawne zarządzanie regionem, przekładając się na problemy społeczne i gospodarcze, przede wszystkim na coraz gorsze wyniki Kalifornii w ogólnoamerykańskich rankingach podsumowujących jakość kształcenia w szkołach publicznych czy ocenach warunków zapewniania przyjaznego klimatu dla rozwoju przedsiębiorczości ${ }^{10}$.

Argumentując tak drastyczną zmianę podziału administracyjnego, Draper odwołał się do danych liczbowych. Jego zdaniem każdy z sześciu nowych stanów pod kątem liczby mieszkańców, poziomu zarobków czy stopy bezrobocia nie odbiegałby od pozostałych stanów USA, a w przypadku niektórych wskaźników, np. dochodu na mieszkańca czy liczby pojawiających się nowych miejsc pracy, z powodzeniem mógłby je wyprzedzić. Co więcej, taki podział najpełniej odzwierciedlałby istniejące w Kalifornii rozbieżności kulturowe i uwzględniałby nierzadko całkowicie odmienne sympatie polityczne mieszkańców. Byłby również zgodny z naturalnym ukształtowaniem terytorium Złotego Stanu, likwidując istniejące trudności komunikacyjne pomiędzy jego poszczególnymi częściami. Takie rozwiązanie zdaniem inwestora z Krzemowej Doliny miałoby również swoje uzasadnienie organizacyjne - ułatwiłoby skuteczniejsze zarządzanie terenami Kalifornii oraz z konieczności zakończyłoby wszelkie inne dzielące mieszkańców przedsięwzięcia secesjonistyczne, gwarantując pełną koncentrację na poprawie ekonomicznych i społecznych warunków życia obywateli nowych stanów [Draper 2014].

W przeciwieństwie do większości wcześniejszych ruchów secesjonistycznych, których przedsięwzięcia zakończyły się na sferze deklaratywnej, projekt Drapera w ciągu dwóch miesięcy od złożenia w biurze Prokuratora Generalnego Kalifornii stał się oficjalną inicjatywą obywatelską. Zyskał formalną akceptację ówczesnej Sekretarz Stanu Kalifornii Debry Bowen i został skierowany do dalszych prac legislacyjnych mających poddać go pod powszechne głosowanie na terenie Złotego Stanu. Przedsięwzięcie zdobyło również znaczną grupę sympatyków. Zwolennikom projektu ,sześciu Kalifornii" udało się zebrać ponad 800000 wymaganych pod inicjatywą podpisów w niecałe pięć miesięcy, co miało zapewnić powszechne głosowanie nad pomysłem na terenie całej Kalifornii już w listopadzie 2016 r. [Fields 2014]. W związku z tym, że administracja stanowa zakwestionowała poprawność części podpisów, inicjatywa w takiej postaci została odrzucona. Nie oznacza to jednak, że jej zwolennicy złożyli ostatecznie broń. Jak informował na stronie internetowej projektu sam Draper, zwolennicy „sześciu Kalifornii” sformalizowali swoją współpracę w ramach powołanej organizacji Innovate Your State ${ }^{11}$, a secesjonistyczne pomysły grupy stały się funda-

${ }^{10}$ Tim Draper argumentował m.in., że California spadła z czołówki na 47 miejsce w kwestii jakości nauczania w szkołach publicznych oraz że zajmuje ostatnie miejsce na wszystkie stany USA, jeśli chodzi o przyjazny klimat dla rozwoju biznesu [Draper 2014].

${ }^{11}$ Dosłownie: „Wprowadź zmiany w swoim stanie”. 
mentem nowego „Zadania Naprawy Kalifornii” (,The Fix California Challenge”) [Draper 2015].

Tabela 2. Projekty secesjonistyczne w Kalifornii w XXI wieku

\begin{tabular}{|c|c|c|c|}
\hline Rok & $\begin{array}{c}\text { Pomysło- } \\
\text { dawca }\end{array}$ & Proponowane zmiany & Oficjalne przyczyny secesji \\
\hline 2003 & Tim Holt & $\begin{array}{l}\text { Podział stanu na cztery nowe jednostki administracyjne: } \\
\text { Redwood Coast i Shasta/Jefferson (obydwa w północnej } \\
\text { części obecnego stanu), Bay Area (obejmujący obszar wo- } \\
\text { kół San Francisco) oraz Central Valley (centralna i połu- } \\
\text { dniowa część Kalifornii) }\end{array}$ & $\begin{array}{l}\text { Trudne do pogodzenia roz- } \\
\text { bieżności polityczne pomiędzy } \\
\text { poszczególnymi częściami Ka- } \\
\text { lifornii }\end{array}$ \\
\hline 2009 & Bill Maze & $\begin{array}{l}\text { Utworzenie Kalifornii Nadbrzeżnej (Coastal California) } \\
\text { z terenów zachodnich hrabstw: Marin, Contra Costa, Ala- } \\
\text { meda, San Francisco, San Mateo, Santa Clara, Santa Cruz, } \\
\text { San Benito, Monterey, San Luis Obispo, Santa Barbara, } \\
\text { Ventura, Los Angeles }\end{array}$ & $\begin{array}{l}\text { Przyczyny ekonomiczne - spo- } \\
\text { sób na rozwiązanie problemów } \\
\text { Kalifornii z recesją }\end{array}$ \\
\hline 2011 & Jeff Stone & $\begin{array}{l}\text { Utworzenie Kalifornii Południowej (South California) z te- } \\
\text { renów hrabstw: Riverside, Imperial, San Diego, Orange, } \\
\text { San Bernardino, Kings, Kern, Fresno, Tulare, Inyo, Madera, } \\
\text { Mariposa, Mono }\end{array}$ & $\begin{array}{l}\text { Przyczyny polityczne - chęć } \\
\text { zgromadzenia w nowym two- } \\
\text { rze administracyjnym bardziej } \\
\text { konserwatywnych hrabstw po- } \\
\text { łudniowo-wschodnich }\end{array}$ \\
\hline 2013 & Mark Baird & $\begin{array}{l}\text { Propozycja połączenia terenów północnej Kalifornii (hrab- } \\
\text { stwa: Del Norte, Siskiyou, Modoc) z obszarem południo- } \\
\text { wego Oregonu (hrabstwa: Curry, Josephine, Jackson, Kla- } \\
\text { math) w nowy stan ,Jefferson” (State of Jefferson) }\end{array}$ & $\begin{array}{l}\text { Protest przeciwko infrastruktu- } \\
\text { ralnym i gospodarczym zanie- } \\
\text { dbaniom tych terenów przez } \\
\text { władze federalne i stanowe } \\
\end{array}$ \\
\hline 2013 & Tim Draper & $\begin{array}{l}\text { Podział stanu na sześć części: } \\
\text { 1. Stan Jefferson (Jefferson) - hrabstwa: Modoc, Lassen, } \\
\text { Plumas, Butte, Glenn, Colusa, Lake, Mendocino, Hum- } \\
\text { boldt, Trinity, Tehama, Shasta, Del Norte, Siskiyou } \\
\text { 2. Kalifornia Zachodnia (West California) - hrabstwa: Los } \\
\text { Angeles, Ventura, Santa Barbara, San Luis Obispo, Kern } \\
\text { 3. Krzemowa Dolina (Silicon Valley) - hrabstwa: Contra } \\
\text { Costa, Alameda, Santa Clara, San Benito, Monterey, Santa } \\
\text { Cruz, San Mateo, San Francisco } \\
\text { 4. Kalifornia Srodkowa (Central California) - hrabstwa: } \\
\text { Inyo, Mono, Alpine, Calaveras, Tuolumne, Mariposa, } \\
\text { Madera, Fresno, Kings, Tulare, Merced, Stanislaus, San } \\
\text { Joaquin } \\
\text { 5. Kalifornia Północna (North California) - hrabstwa: Sier- } \\
\text { ra, Nevada, Placer, El Dorado, Amador, Sacramento, Sola- } \\
\text { no, Marin, Napa, Sonoma, Yolo, Sutter, Yuba } \\
\text { 6. Kalifornia Południowa (South California) - hrabstwa: } \\
\text { San Bernardino, Riverside, Imperial, San Diego, Orange }\end{array}$ & $\begin{array}{l}\text { Przyczyny polityczne i ekono- } \\
\text { miczne - powierzchnia i prze- } \\
\text { ludnienie stanu przekładają się } \\
\text { na nieefektywność władzy, a to } \\
\text { z kolei na problemy społeczne } \\
\text { i gospodarcze Kalifornii }\end{array}$ \\
\hline
\end{tabular}

Źródło: Opracowanie własne na podstawie: Mathews, Paul 2010: 154-155; Laufer 2014: 27; Romney 2013; Holt 2003; Draper 2014.

\section{ZAKOŃCZENIE}

Choć projekt Tima Drapera został odrzucony i ma coraz mniej szans na ponowną formalną akceptację w stanowej legislaturze, a tym samym na możliwość procedowania go w przyszłości, to fakt zgromadzenia setek tysięcy zwolenników utworzenia 
„sześciu Kalifornii” pokazuje nie tylko determinację oraz niebywały optymizm współczesnych secesjonistów, lecz także nastroje niezadowolenia społecznego narastające wśród mieszkańców jednego z najbogatszych i najbardziej otwartych stanów USA. Jest to szczególnie wymowne, gdy porównamy publiczną retorykę Drapera z cytowanymi powyżej wypowiedziami Balaji Srinivasana. W obydwu wypadkach kluczową przyczyną pojawiających się propozycji secesjonistycznych wydaje się być czynnik ekonomiczny wyrażający się w przekonaniu, że opuszczenie Kalifornii jest w interesie jej mieszkańców. Sama forma nowej państwowości - realna czy wirtualna - ma tu znaczenie drugorzędne. Istotą jest niezadowolenie społeczne przekuwające się spontanicznie w ruch polityczny przekonany o możliwości dokonania fundamentalnego przeobrażenia wspólnoty przy pomocy mechanizmów demokratycznych oraz zdeterminowany do tego, aby podjąć to wyzwanie.

W przypadku samej Kalifornii pewne jest natomiast to, że polityczna niepokorność i przedsiębiorczość jej mieszkańców połączona z umiejętnie pielęgnowanymi tradycjami niepodległościowymi stanu zapewnią pojawienie się w niedługim czasie nowych pomysłów i przedsięwzięć secesjonistycznych. I choć wzorem wcześniejszych nie osiągną one swoich celów, stając się krótkotrwałą „lokalną fanaberią polityczną", wciąż będą miały znaczenie z punktu widzenia społeczeństwa. Pozostaną bowiem miernikiem wolności politycznej Amerykanów i namacalnym dowodem gwarantowanego przez Ojców Założycieli w „Deklaracji Niepodległości” prawa obywateli do samostanowienia.

\section{BIBLIOGRAFIA}

Allen, N. 2011. Could 'South California'become the 51st US state?, „The Telegraph” 11.07, http://www. telegraph.co.uk/ (dostęp: 29.12.2015).

Annual Estimates of the Resident Population for the United States, Regions, States, and Puerto Rico: April 1, 2010 to July 1, 2015, 2015, U.S. Census Bureau, http://www.census.gov/ (dostęp: 29.12.2015).

Bartnicki, A., Michałek, K., Rusinowa, I. 1992. Encyklopedia Historii Stanów Zjednoczonych Ameryki, Warszawa.

Bluff, R. 2014. State of Jefferson: 2 of 3 Northern California secession measures defeated, „The San Jose Mercury News" 04.06, http://www.mercurynews.com/ (dostęp: 29.12.2015).

Di Leo, M., Smith, E. 1983. Two Californias: The Myths And Realities Of A State Divided Against Itself, Island Press, Covelo.

Draper, T. 2014. Six Californias. Initiative measure submitted directly to voters, http://www.sixcalifornias. com/ (dostęp: 29.12.2015).

Draper, T. 2015. Initiative Status of Six Californias, http://www.sixcalifornias.com/ (dostęp: 29.12.2015).

Ellison, W.H. 1913. The Movement for State Division in California, 1849-1860, „The Southwestern Historical Quarterly", vol. 7, $\mathrm{nr} 2$.

Evans, J. 2002. Upstate, downstate, „Sacramento News and Review” 03.01, https://www.newsreview.com (dostęp: 29 grudnia 2015).

Fields, K. 2014 Petition to Split California Into Six States Gets Green Light, „ABC News” 19.02, http:// abcnews.go.com/ (dostęp: 29.12.2015). 
Gall, T.L. 2007 Worldmark Encyclopedia of the States, vol. 1, Thomson Gale, Detroit-New York-San Francisco-London.

Holt, T. 2003. A modest proposal - downsize California!, „The San Francisco Chronicle” 17.08, http:// www.sfgate.com/ (dostęp: 29.12.2015).

Janiskee, B.P., Masugi, K. 2004. The California Republic: Institutions, Statesmanship, and Policies, Rowman and Littlefield Publishers, Inc., Lanham-Boulder-New York-Toronto-Oxford.

Kamber, V. 1995. Giving Up on Democracy: Why Term Limits Are Bad for America, Washington.

Laufer, P. 2014. All We Ask Is To Be Left Alone, „Humboldt Journal of Social Relations”, nr 36.

Mathews, J., Paul, M. 2010. California Crackup: How Reform Broke the Golden State and How We Can Fix It, University of California Press, Berkeley-Los Angeles-London.

Pavkovic, A., Radan, P. 2007. Creating New States: Theory and Practice of Secession, ASHGATE, Aldershot-Burlington.

Pomarański, M. 2013. Wspótczesny amerykański fundamentalizm protestancki, Lublin.

Romney, L. 2013. Modoc becomes second California county to back secession drive, „The Los Angeles Times" 25.08, http://www.latimes.com/ (dostęp: 29.12.2015).

Sarnacka-Mahoney, E. 2013. Nowy stan w USA: z waluta Bitcoin, akademia Khana i drukarkami 3D, „Dziennik Gazeta Prawna” 5.11, http://wiadomosci.dziennik.p1/ (dostęp: 29.12.2015).

Srinivasan, B. 2013. Balaji Srinivasan on Silicon Valley's ultimate exit, https://nydwracu.wordpress. com/2013/10/28/transcript-balaji-srinivasan-on-silicon-valleys-ultimate-exit/ (dostęp: 29.12.2015).

Wood, D.B. 2011. 51st state? Small step forward for long-shot 'South California' plan, „Christian Science Monitor" 12.07, http://www.csmonitor.com/ (dostęp: 29.12.2015).

ABSTRACT

The aim of the study is the answer to the question about the condition and size of American secessionist movements in the twenty-first century. In particular, the discussion will focus on the California's secessionist projects: an attempt to capture the essence of such projects, to identify the causes of radical demands and to analyze the social impact of these projects on the Golden State and its inhabitants. Reference to the example of California seems especially justified here. As the third largest, and the first - in terms of the number of population - state in the US, it can boast an extremely rich tradition of independence, resulting in hundreds of various projects seeking to divide or to gain independence for the area.

Key words: secession, secessionist movement, California

BIOGRAM

Marcin Pomarański, politolog i filozof, doktor nauk humanistycznych, adiunkt w Zakładzie Ruchów Politycznych Wydziału Politologii UMCS w Lublinie. Autor publikacji naukowych podejmujących problematykę współczesnych ruchów politycznych w Stanach Zjednoczonych Ameryki, relacji państwa z Kościołami, współczesnego ekstremizmu religijnego i politycznego, a także form współczesnego protestu politycznego. Autor monografii Współczesny amerykański fundamentalizm protestancki. Kontakt e-mail: mpomaran@gmail.com. 